five sea birds from Lancaster Sound. Renewable Resources Consulting Services Ltd., 55 p.

Sellström, U., Jansson, B., Kierkegaard, A., de Wit, C., Odsjö, T., Olsson, M., 1993. Polybrominated diphenyl ethers (PBDE) in biological samples from the Swedish environment. Chemosphere 26, 1703-1718.

Simon, M., Wakeford, B.J., 2000. Multiresidue method for the determination of polychlorinated dibenzo-p-dioxins, polychlorinated dibenzofurans and non-ortho substituted polychlorinated biphenyls in wildlife tissue by HRGC/HRMS. Technical Report Series No. 336E, Canadian Wildlife Service, Headquarters, Hull, Quebec, Canada, $41 \mathrm{p}$.

Stern, G.A., Ikonomou, M., 2000. Temporal trends of polybrominated biphenyls and polybrominated and polychlorinated diphenyl ethers in southeast Baffin beluga. In: Kalhok, S. (Ed.), Synopsis of Research Conducted Under the 1999-2000 Northern Contaminants Program. Indian Affairs and Northern Development Canada, Ottawa, pp. 227-232.

Thompson, D.R., 1996. Mercury in birds and terrestrial mammals. In: Beyer, W.N., Heinz, G.H., Redmon-Norwood, A.W. (Eds.), Environmental Contaminants in Wildlife: Interpreting Tissue
Concentrations. In: SETAC Special Publications Series. CRC Press, New York, pp. 341-356.

Tittlemier, S.A., Fisk, A.T., Hobson, K.A., Norstrom, R.J., 2002. Examination of the bioaccumulation of halogenated dimethyl bipyrroles in an Arctic marine food web using stable nitrogen isotope analysis. Environmental Pollution 116, 8593.

Tittlemier, S.A., Simon, M., Jarman, W.M., Elliott, J.E., Norstrom, R.J., 1999. Identification of a novel $\mathrm{C}_{10} \mathrm{H}_{6} \mathrm{~N}_{2} \mathrm{Br}_{4} \mathrm{Cl}_{2}$ heterocyclic compound in seabird eggs. A bioaccumulating marine natural product? Environmental Science and Technology 33, 26-33.

Tsukamoto, K., Nakai, I., Tesch, W.-V., 1998. Do all freshwater eels migrate? Nature 396, 635-636.

Wideqvist, U., Jansson, B., Olsson, M., Odsjö, T., Reutergårdh, L., Uvemo, U.-B., 1993. Temporal trends of PCC in guillemot eggs from the Baltic. Chemosphere 27, 1987-2001.

Wiemeyer, S.N., 1996. Other organochlorine pesticides in birds. In: Beyer, W.N., Heinz, G.H., Redmon-Norwood, A.W. (Eds.), Environmental Contaminants in Wildlife: Interpreting Tissue Concentrations. In: SETAC Special Publications Series. CRC Press, New York, pp. 99-115.

\title{
Baseline study of perfluorochemicals in harbour porpoises (Phocoena phocoena) from Northern Europe
}

\author{
K.I. Van de Vijver ${ }^{\text {a,* }}$, P.T. Hoff ${ }^{\text {a }}$, K. Das ${ }^{\text {b,c }}$, W. Van Dongen ${ }^{d}$, E.L. Esmans ${ }^{\text {d }}$, \\ U. Siebert ${ }^{\mathrm{c}}$, J.M. Bouquegneau ${ }^{\mathrm{b}}$, R. Blust ${ }^{\mathrm{a}}$, W.M. De Coen ${ }^{\mathrm{a}}$ \\ a Department of Biology, University of Antwerp, Groenenborgerlaan 171, 2020 Antwerpen, Belgium \\ ${ }^{\mathrm{b}}$ Laboratory for Oceanology, MARE Center, Liège University B6c, B-4000 Liège, Belgium \\ ${ }^{\mathrm{c}}$ Forschung und Technologiezentrum Westkueste, Christian-Albrechts-Universitaet Kiel, Werfstrasse 6, D-25761 Buesum, Germany \\ ${ }^{\mathrm{d}}$ Nucleoside Research and Mass Spectrometry Unit, University of Antwerp, Universiteitsplein 1, 2610 Wilrijk, Belgium
}

Received 9 December 2003; received in revised form 13 January 2004; accepted 13 February 2004

The harbour porpoise (Phocoena phocoena) is one of the smallest of all whale species, and inhabits many coastal areas in the Northern Hemisphere. This species is found in the shallow, cold temperate and sub-arctic waters of the Atlantic coast of Europe, east and west coasts of North America and the Pacific coast of Asia (Reid et al., 2003). In North-Europe, the species is common around Norway, Iceland and Denmark (Hammond et al., 2002). The harbour porpoise has almost disappeared from the Baltic Sea and the winter migration between the Baltic and North Sea has decreased (Jefferson and Curry, 1994; Koschinski, 2002). The harbour porpoise population in the North Atlantic

\footnotetext{
${ }^{*}$ Corresponding author. Tel.: +32-3-265-3350; fax: +32-3-2653497.

E-mail address: inneke.vandevijver@ua.ac.be (K.I. Van de Vijver).
}

has been targeted both by direct hunting and as by-catch in commercial fisheries throughout their range (Jefferson and Curry, 1994). Declines in porpoise populations may also be directly related to habitat loss (e.g. coastal development), prey depletion from commercial fishery and pollution (Jepson et al., 1999; Siebert et al., 1999; Johnston, 2002). Previous studies on organochlorinated contaminants reported high concentrations in harbour porpoises from Danish and Scandinavian waters (Clausen and Andersen, 1988; Kleivane et al., 1995), the Baltic Sea (Berggrena et al., 1999) and the Southern North Sea (Covaci et al., 2002). In recent years, a growing concern has been expressed about another class of organohalogen chemicals, namely perfluorinated organic compounds (FOCs). Results of previous studies suggest that perfluorochemicals, in particular, perfluorooctane sulfonic acid (PFOS), are spread worldwide in 
wildlife and in humans (Giesy and Kannan, 2001; Kannan et al., 2001a,b, 2002; Olsen et al., 1999). Even in remote arctic areas such as the Arctic Ocean, a detectable amount of fluorinated organochemicals could be quantified in the blood or organs, such as liver and kidney, of wildlife (e.g. fish, birds and marine mammals) (Giesy and Kannan, 2001). Accumulation patterns seem to be different from those observed for other organohalogen compounds, like PCBs and DDTs, since no clear relationship with age and/or sex could be determined.

The first aim of the present study was to evaluate the occurrence and trends of PFOS and related compounds in by-caught harbour porpoises from coastal waters around Iceland, Norway and Denmark and in the German Baltic Sea. The second aim was to reveal the possibility of using fluorinated compound profiles to discriminate different harbour porpoise populations from different Norwegian water regions. This was done by combining our pollutant exposure data to stable isotope measurements previously described (Das et al., 2003; Fontaine et al., Unpublished data). At present, population genetics and behavioural analysis is used to further characterise the different porpoise populations from this region. The harbour porpoise is thought to be predominantly a coastal species, but sighting surveys showed that it is quite capable of being pelagic, suggesting different populations in Norwegian waters (Donovan and Bjørge, 1995).

Liver samples were collected from 41 harbour porpoises (Phocoena phocoena) caught incidentally in fishing nets along the coasts of the Germany Baltic Sea $(n=7)$, Denmark $(n=7)$, Iceland $(n=8)$ and Norway $(n=19)$. The harbour porpoises caught along the Norwegian coast were divided into two regional groups (North Norway/Barents Sea: $n=11$ and Southwest coast: $n=$ 8). Post-mortem investigations were done according to a standard protocol (Kuiken and Hartmann, 1993). Details concerning necropsy, body condition and lesions of the respiratory tract and parasite load have been published previously (Siebert et al., 1999, 2001). Samples were stored at $-20{ }^{\circ} \mathrm{C}$ until further analyses.

Concentrations of perfluorinated compounds in liver tissue extracts were determined using high performance liquid chromatography combined with electrospray tandem mass spectrometry (HPLC-MS/MS) as described by Hansen et al. (2001) with modifications described by Hoff et al. (2003). Perfluorooctanoic acid (PFOA), perfluorononanoic acid (PFNA), perfluorooctane sulfonic acid (PFOS), perfluorodecanoic acid (PFDA), perfluoroundecanoic acid (PFUA) and perfluorododecanoic acid (PFDoA) were measured in all liver samples. Briefly, HPLC was done on a CapLC system (Waters, Millford, MA, USA) connected to a Quattro II triple quadrupole mass spectrometer (Micromass, Manchester, UK). Aliquots of $5 \propto l$ of extract were loaded on an Optiguard C18 pre-column (10 $\mathrm{mm} \times 1 \mathrm{~mm}$ i.d., Alltech, Sercolab, Belgium), followed by a Betasil $\mathrm{C} 18$ column $(50 \mathrm{~mm} \times 1 \mathrm{~mm}$ i.d., Keystone Scientific, Bellefonte, PA, USA) at a flow rate of $40 \propto l$ $\min ^{-1}$. The mobile phase was $2 \mathrm{mM} \mathrm{NH} \mathrm{H}_{4} \mathrm{OAc} / \mathrm{CH}_{3} \mathrm{OH}$, starting at $10 \%$ methanol and increasing to $90 \%$ in 8 min. After $10 \mathrm{~min}$ initial conditions were resumed. All components were measured under negative electrospray ionisation using the following transitions $413 \rightarrow 369$ (PFOA), $463 \rightarrow 419 \quad$ (PFNA), $499 \rightarrow 99 \quad$ (PFOS), $513 \rightarrow 469$ (PFDA), $563 \rightarrow 519$ (PFUA) and $613 \rightarrow 569$ (PFDoA). Perfluoro-1-octanesulfonic acid, tetraethylammonium salt, with a purity of $98 \%$ was used as PFOS standard and purchased from Aldrich Chemical Company, Inc. (Milwaukee, USA). The results were not corrected for the purity. The internal standard, $1 \mathrm{H}, 1 \mathrm{H}$, 2H, 2H-PFOS (Sigma-Aldrich Chemical Company, Milwaukee, WI, USA) was measured under the same conditions $(427 \rightarrow 81)$. The dwell time was $0.1 \mathrm{~s}$. The EScapillary voltage was set at $-3.5 \mathrm{kV}$ and the cone voltage was $24 \mathrm{~V}$. The source temperature was $80{ }^{\circ} \mathrm{C}$. The pressure in the collision cell was $3.3 \times 10^{-5} \mathrm{~mm} \mathrm{Hg}$ (Ar). The detection limit of PFOS was $10 \mathrm{ng} \mathrm{g}^{-1}$ wet weight, whereas for the other measured compounds it varied from 1.54 to $62.11 \mathrm{ng} \mathrm{g}^{-1}$ wet weight.

Muscle tissues were analysed for stable isotope measurements. After drying at $50{ }^{\circ} \mathrm{C}(48 \mathrm{~h})$, samples were ground into a homogeneous powder and treated with a 2:1 chloroform:methanol solution to remove lipids. After drying at $50{ }^{\circ} \mathrm{C}(48 \mathrm{~h})$, samples were ground into a homogeneous powder. Carbon dioxide and nitrogen gas were analysed as described previously (Das et al., 2003) on a V.G. Optima (Micromass) IR-MS coupled to a $\mathrm{N}-\mathrm{C}-\mathrm{S}$ elemental analyser (Carlo Erba) for automated analyses. Routine measurements are precise to 0.3 for both 13-carbon and 15-nitrogen. Stable isotope ratios were expressed in notation according to the following:

$\delta X=\left[\left(R_{\text {sample }} / R_{\text {standard }}\right)-1\right] \times 1000$

where $X$ is ${ }^{13} \mathrm{C}$ or ${ }^{15} \mathrm{~N}$ and $R$ is the corresponding ratio ${ }^{13} \mathrm{C} /$ ${ }^{12} \mathrm{C}$ or ${ }^{15} \mathrm{~N} /{ }^{14} \mathrm{~N}$. Carbon and nitrogen ratios are expressed relative to the v-PDB (Vienna Peedee Belemnite) standard and to atmospheric nitrogen, respectively. Reference materials were IAEA-N $1\left(\delta^{15} \mathrm{~N}=+0.4 \pm 0.2\right)$ and IAEA CH-6 (sucrose) $\left(\delta^{13} \mathrm{C}=-10.4 \pm 0.2\right)$.

To compare the levels of PFOS in liver tissue of harbour porpoises among the different countries we used a non-parametric Kruskal-Wallis test as the data showed heterogeneity of variances among the different groups (Levenes test). Pairwise comparisons were made using a Mann-Withney $U$-test. The significant difference level was set at $p<0.05$. This non-parametric test was also used to compare the levels of PFOS in the different regional groups of Norway (North Norway/Barents Sea and the Southwest coast). An unpaired $t$-test was used to 
compare the mean concentrations of the other perfluorinated compounds between the different locations. In cases where the variances were not equal, an unpaired $t$-test with Welch corrections was performed. It was not possible to investigate the effects of sex and age within the different regions or countries due to the small sample size at each location. Taking all groups together would certainly introduce some bias due to regional differences in the levels of PFOS. An unpaired $t$-test was performed to describe the difference in stable carbon isotope ratio $\left(\delta^{13} \mathrm{C}\right)$ between the porpoises of North Norway/Barents Sea and those of the Southwest coast. All analyses were performed using the software package Statistica (Statsoft Inc., Tulsa, Oklahoma, US).

Of all perfluorinated chemicals measured in livers of by-caught harbour porpoises from Iceland, Norway, Denmark and the German Baltic Sea, PFOS seemed to be the predominant compound. Levels of PFOS ranged from $26 \mathrm{ng} \mathrm{g}^{-1}$ tissue to $1149 \mathrm{ng} \mathrm{g}^{-1}$. However, a geographical difference could be observed with a decreasing trend in contaminant levels from south to north. Porpoises from the German Baltic Sea showed significantly higher PFOS levels than porpoises from Norway and Iceland $(p<0.01)$. Harbour porpoises of Iceland showed the lowest PFOS concentrations with a mean concentration of $38 \pm 14 \mathrm{ng} \mathrm{g}^{-1}$ tissue and this value was significant lower than the mean concentration of PFOS in harbour porpoises from Norway $\left(213 \pm 195 \mathrm{ng} \mathrm{g}^{-1}\right)$, Denmark $\left(270 \pm 171 \mathrm{ng} \mathrm{g}^{-1}\right)$ and the German Baltic Sea $\left(534 \pm 357 \mathrm{ng} \mathrm{g}^{-1}\right)(p<0.001$ in all cases) (Fig. 1a).

A comparison of the mean concentrations of PFDA, PFUA and PFDoA in the liver tissue of harbour porpoises from the different locations is given in Fig. $1 \mathrm{~b}-\mathrm{d}$, respectively. Concentrations of PFOA were all, except for one sample, under the detection limit of $62 \mathrm{ng} \mathrm{g}^{-1}$ wet wt. Only 15 samples of a total of 37 contained detectable PFNA concentrations (range from $<14$ to 47 $\mathrm{ng} \mathrm{g}^{-1}$ wet wt). Due to the small sample size, no relevant comparison between different locations could be performed. The highest hepatic concentrations of PFDA and PFUA were detected in harbour porpoises from the German Baltic Sea, followed by individuals from Denmark $>$ Iceland $>$ Norway. The highest mean hepatic concentration of PFDoA was measured in the liver of porpoises from the Baltic Sea, and the lowest in porpoises from the waters around Iceland. However, the concentrations found in animals from Iceland and Norway were very similar for all perfluorinated compounds measured. For all locations, PFOS concentrations were significant higher than the other perfluorinated compounds.

Concentrations of all compounds (PFOS, PFDA, PFUA, PFDoA) measured were higher in liver tissue of porpoises from the Baltic Sea than those from Iceland and Norway. A difference in pollution burden is likely between the different locations. As there are no known natural sources of PFOS and related substances, their presence in the environment is due solely to anthropogenic activity. Although sparse information on the use of these chemicals is available from northern and eastern countries bordering the Baltic Sea, these results are not surprising since the Baltic Sea region is a highly urbanized and industrialized location and seems to show higher levels of several pollutants (e.g. PCBs, DDTs, HCHs) compared to less industrialized environments (Kleivane et al., 1995; Bruhn et al., 1999; Berggrena et al., 1999). Earlier studies have also reported the highest PFOS concentrations in plasma and liver tissue of seals originating from the Baltic Sea (Giesy and Kannan, 2001; Kannan et al., 2002). The low concentrations of perfluorochemicals in porpoises captured in the Icelandic and Norwegian waters are on one hand an indication of the low pollution burden in the region (there is no known production of PFOS in these regions). On the other hand, the presence of PFOS and other perfluorinated substances at the locations monitored show once more that perfluorinated chemicals occur worldwide, even in more remote marine environments with no apparent perfluorochemical production activity.

Within the Norwegian samples, a significant difference could be detected between the mean concentrations of PFOS of porpoises from North Norway/Barents Sea $\left(118.24 \pm 44.70 \mathrm{ng} \mathrm{g}^{-1}\right)$ and the Southwest coast of Norway $\left(343.91 \pm 248.50 \mathrm{ng} \mathrm{g}^{-1}\right)(p<0.05)$. In contrast to the hepatic PFOS concentration, no difference could be detected between the different Norwegian locations for PFUA. Analysis of the stable isotope ratios of muscle tissue of harbour porpoises of two regions in Norway showed that there is a difference in feeding habits, regarding food source, between porpoises from North Norway/Barents Sea and the Southwest region (Fontaine et al., Unpublished data). The unpaired $t$-test revealed a significant difference $(p<0.0001)$ between the mean $\delta^{13} \mathrm{C}$ values of North Norway/Barents Sea $(-19.0 \pm 0.4, n=11)$ and those from the Southwest $(-17.9 \pm 0.4, n=8)$.

According to the International Whaling Commission there are 3 populations of harbour porpoises along the Norwegian coast: (1) in the Kattegat and adjacent waters, (2) in the North Sea and (3) in the North of Norway and the Barents Sea (Tolley and Heldal, 2002). The boundary between the North Sea population and that of North Norway lies at $66^{\circ} \mathrm{N}$. The difference in PFOS levels in porpoises from North Norway/Barents Sea and the Southwest coast of Norway provide some biological evidence for the division proposed by the IWC. North Norway porpoises show significantly lower levels of PFOS than those from the Southwest coast. Combining this information with the data of the stable carbon isotopes, our results suggest that porpoises of North Norway/Barents Sea feed more offshore, and porpoises of 

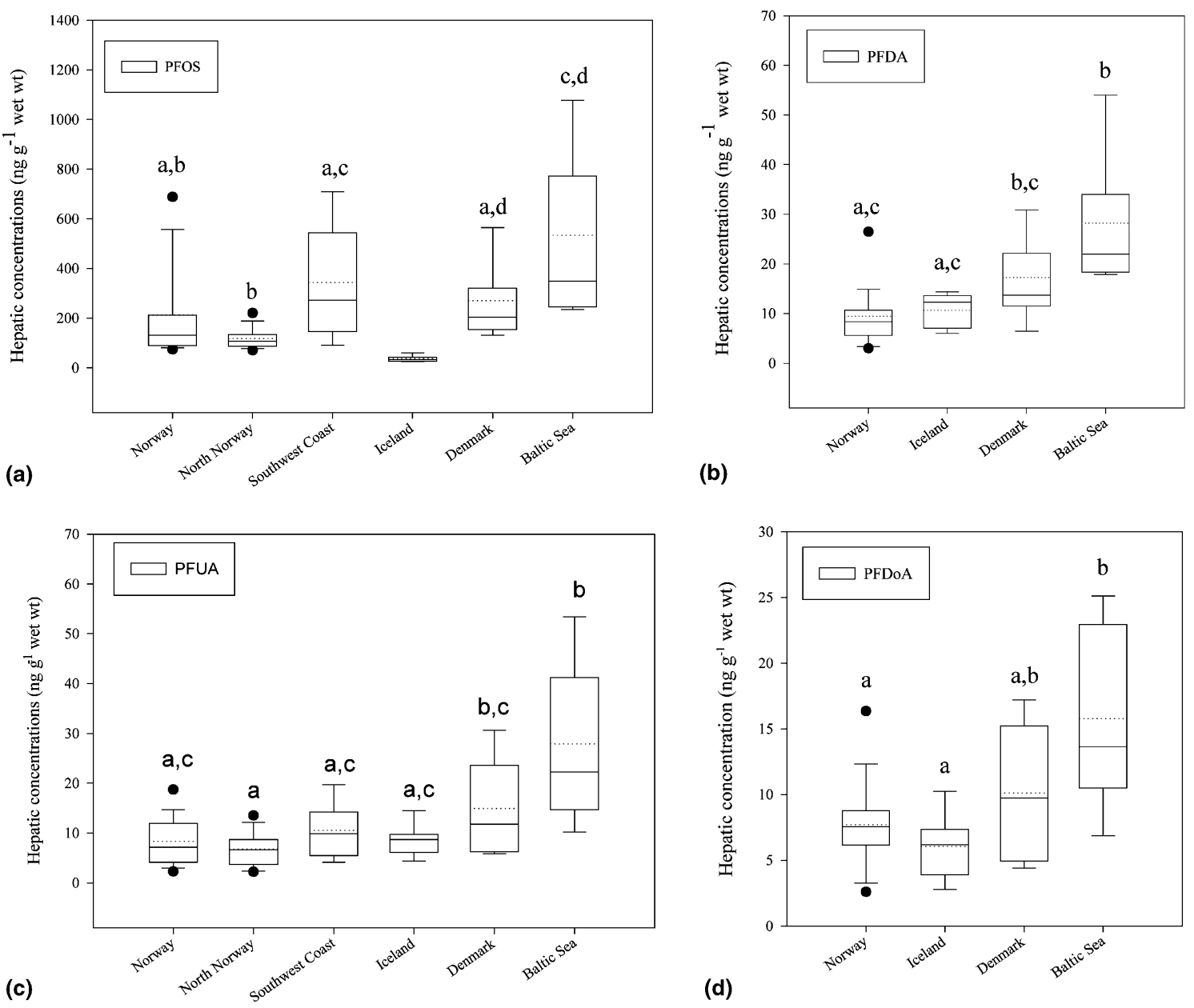

(b)

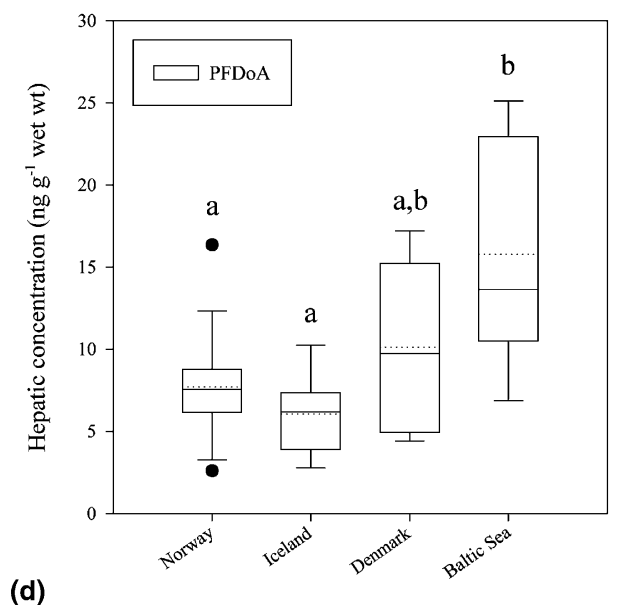

Fig. 1. Hepatic concentrations of respectively (a) perfluorooctane sulfonic acid (PFOS), (b) perfluorodecanoic acid (PFDA), (c) perfluoroundecanoic acid (PFUA) and (d) perfluorododecanoic acid (PFDoA) in the liver of harbour porpoises drowned in gillnets at different sites in waters around Northern Europe. The straight line is the median and the dotted line represents the mean. The 25th and 75th percentiles define the boxes. The whiskers represent the 10th and 90th percentiles, while the dots represent the 5th and 95th percentiles. The lower cases a, b, c and d indicate the significant differences between the groups.

the Southwest Coast feed more in coastal waters. Previous studies have reported that coastal regions seem to be more polluted than oceanic waters (Kannan et al., 2001a; Van de Vijver et al., 2003a). The new data presented on perfluorinated chemicals around the coasts of Norway seem to confirm such a pollution gradient. The mean PFUA concentration in porpoises from North Norway/Barents Sea was lower than the mean PFUA concentration measured in porpoises from the Southwest Coast; however the difference was not significant. Previous studies, based on measurements of radioactive caesium, have indicated that the porpoises of North Norway and the Barents Sea can be divided into two separate populations (Nordland and Finnmark population) (Tolley and Heldal, 2002). However our sample size of the group from Finmark is too small $(n=3)$ to discriminate various subpopulations.

When comparing PFOC levels between areas, differences in age and gender should be taken into account. Although the sample size of the present study did not allow studying these differences, an important observation should be mentioned. One sample of the North Norway/Barents Sea porpoises belonged to a foetus and its liver tissue showed the highest concentrations of all samples of that region, namely 224 $\mathrm{ng} \mathrm{g}^{-1}$ tissue. The PFOS concentration found in the liver tissue of the mother of this animal was only $87 \mathrm{ng} \mathrm{g}^{-1}$ tissue. In a previous study on marine mammals from the southern North Sea, adult harbour porpoises had significantly lower levels of PFOS in their liver than juveniles (Van de Vijver et al., 2003b). Although, until now, no evidence of a transfer route of perfluorochemicals from mother to offspring has been described in literature, these observations require further attention to allow a correct impact assessment of these chemicals on marine mammal populations. Within the present data sea, no significant relationship could be detected between PFOS concentrations and the length, weight and blubber thickness of the animals. 
Comparing the results of this study with data of PFOS measurements in harbour porpoises from the southern North Sea (93 $\pm 86 \mathrm{ng} \mathrm{g}^{-1}$ tissue), higher levels were found in animals from the German Baltic Sea and Denmark (Van de Vijver et al., 2003b). Concentrations of PFOS in individuals originating from the North Sea were similar to those from Iceland and Norway. No clear explanation can be given for these observations. In contrast to the southern North Sea where a direct pollution source can be found in Antwerp, Belgium, it is presumed that only indirect PFOS sources are present along the Baltic and Danish coasts. One should therefore expect higher concentrations in the southern North Sea. A possible explanation might be the difference between the North Sea as an open sea and the Baltic Sea, which is a semi-enclosed area. The link between the Baltic Sea and the North Sea is very narrow, the shallowest sill being only $18 \mathrm{~m}$ deep. Thus, inflows of salt water must be extremely forceful to penetrate and renew the deepest waters of the Baltic Sea. Therefore, no dilution of present pollutants or distribution to other areas can occur easily (Szefer, 2002).

In conclusion, harbour porpoises from Northern Europe are heavily contaminated with PFOS and to a lesser extent with perfluorocarboxylates. As Iceland is known as a relatively unpolluted area it was expected to find the lowest levels of perfluorinated chemicals over here. The concentration range of PFOS, PFDA, PFUA and PFDoA in the German Baltic Sea was significantly higher compared to Iceland and Norway corresponding to previous reports on increased pollution levels in this area.

\section{Acknowledgements}

The authors are grateful to G. Vikingson (Marine Research Institute, Iceland) and K. Tolley (University of Stellenbosch, South Africa) for providing the samples of Iceland and Norway. K. Van de Vijver has received a grant from the FWO-Flanders, Brussels, Belgium and K. Das has received a Marie-Curie Fellowship. This paper is a MARE publication no. 032 .

\section{References}

Berggrena, P., Ishaq, R., Zebühr, Y., Näf, C., Bandh, C., Broman, D., 1999. Patterns and levels of organochlorines (DDTs, PCBs, nonortho $\mathrm{PCBs}$ and $\mathrm{PCDD} / \mathrm{Fs}$ ) in male harbour porpoises (Phocoena phocoena) from the Baltic Sea, the Kattegat-Skagerrak Seas and the West Coast of Norway. Marine Pollution Bulletin 38, 1070-1084.

Bruhn, R., Kanman, N., Petrick, G., Schulz-Bull, D.E., Duinker, J.C., 1999. Persistent chlorinated organic contaminants in harbour porpoises from the North Sea, the Baltic Sea and Arctic waters. Science of the Total Environment 237/238, 351-361.

Clausen, B., Andersen, S., 1988. Evaluation of bycatch and health status of the harbour porpoise (Phocoena phocoena) in Danish waters. Danish Review of Game Biology 13, 1-20.
Covaci, A., Van de Vijver, K., De Coen, W., Das, K., Bouquegneau, J.M., Blust, R., Schepens, P., 2002. Determination of organohalogenated contaminants in liver of harbour porpoises (Phocoena phocoena) stranded on the Belgian North Sea coast. Marine Pollution Bulletin 44 (10), 1152-1169.

Das, K., Lepoint, G., Leroy, Y., Bouquegneau, J.M., 2003. Marine mammals from the Southern North Sea: feeding ecology data from $\delta^{13} \mathrm{C}$ and $\delta^{15} \mathrm{~N}$ measurements. Marine Ecology Progress Series 263, 287-298.

Donovan, G.P., Bjørge, A., 1995. Harbour porpoises in the North Atlantic: edited extract from the Report of the IWC Scientific Committee, Dublin 1995. Report of the International Whaling Committee Special Issue 16, pp. 3-25.

Fontaine, M.C., Siebert, U., Tolley, K.A., Lepoint, G., Gobert, S., Bouquegneau, J.-M., Das, K., Unpublished data. Feeding ecology of the harbour porpoises (Phocoena phocoena) from the coasts of Norway: fine scale segregation of populations inferred through a combined approach of trace elements and stable isotopes.

Giesy, J.P., Kannan, K., 2001. Global distribution of perfluorooctane sulfonate in wildlife. Environmental Science and Technology 35, 1339-1342.

Hammond, P.S., Berggren, P., Benke, H., Borchers, D.L., Collet, A., Heide-Jorgensen, M.P., Heimlich, S., Hiby, A.R., Leopold, M.F., Oien, N., 2002. Abundance of harbour porpoise and other cetaceans in the North Sea and adjacent waters. Journal of Applied Ecology 39, 361-376.

Hansen, K.J., Clemen, L.A., Ellefson, M.E., Johnson, H.O., 2001. Compound-specific, quantitative characterization of organic fluorochemicals in biological matrices. Environmental Science and Technology 35, 766-770.

Hoff, P.T., Van de Vijver, K., Van Dongen, W., Esmans, E.L., Blust, R., de Coen, W.M., 2003. Perfluorooctane sulfonic acid in bib (Trisopterus luscus) and plaice (Pleuronectes platessa) from the Western Scheldt and the Belgian North Sea: distribution and biochemical effects. Environmental Toxicology and Chemistry 22, 608-614.

Jefferson, T.A., Curry, B.E., 1994. A global review of porpoise (Cetacea: Phocoenidae) mortality in gillnets. Biological Conservation 67, 167-183.

Jepson, P.D., Bennett, P.M., Allchin, C.R., Law, R.J., Kuiken, T., Baker, J.R., Rogan, E., Kirkwood, J.K., 1999. Investigating potential associations between chronic exposure to poychlorinated biphenyls and infectious disease mortality in harbour porpoises from England and Wales. Science of the Total Environment 144, 339-348.

Johnston, D.W., 2002. The effect of acoustic harassment devices on harbour porpoises (Phocoena phocoena) in the Bay of Fundy. Canada. Biological Conservation 108 (1), 113-118.

Kannan, K., Koistinen, J., Beckmen, K., Evans, T., Gorzelany, J.F., Hansen, K.J., Jones, P.D., Helle, E., Nyman, M., Giesy, J.P., 2001a. Accumulation of perfluorooctane sulfonate in marine mammals. Environmental Science and Technology 35, 15931598.

Kannan, K., Franson, J.C., Bowerman, W.W., Hansen, K.J., Jones, P.D., Giesy, J.P., 2001b. Perfluorooctane sulfonate in fish-eating water birds including bald eagles and albatrosses. Environmental Science and Technology 35, 3065-3070.

Kannan, K., Corsolini, S., Falandysz, J., Oehme, G., Focardi, S., Giesy, J.P., 2002. Perfluorooctanesulfonate and related fluorinated hydrocarbons in marine mammals, fishes, and birds from coasts of the Baltic and the Mediterranean Seas. Environmental Science and Technology 36, 3210-3216.

Kleivane, L., Skaare, J.U., Bjørge, A., de Ruiter, E., Reijnders, P.J.H., 1995. Organochlorine pesticide residue and PCBs in Harbour Porpoise (Phocoena phocoena) incidentially caught in Scandinavian waters. Environmental Pollution 89 (2). 
Koschinski, S., 2002. Current knowledge on harbour porpoises (Phocoena phocoena) in the Baltic Sea. Ophelia 55 (3), 167-197.

Kuiken, T., Hartmann, M.G., 1993. Cetacean pathology dissection techniques and tissue sampling. Proceedings of the European Cetacean Society Workshop, Leiden, p. 39.

Olsen, G.W., Burris, J.M., Mandel, J.H., Zobel, L.R., 1999. Serum perfluorooctane sulfonate and hepatic and lipid clinical chemistry tests in fluorochemical production employees. Journal of Occupational and Environmental Medicine 41, 799-806.

Reid, J.B., Evans, P.G.H., Northridge, S.P., 2003. Atlas of Cetacean Distribution in North-west European Waters, Peterborough: Joint Nature Conservation Committee.

Siebert, U., Joiris, C., Holsbeek, L., Benke, H., Failing, K., Failing, K., Frese, K., Petzinger, E., 1999. Potential Relation between mercury concentrations and necropsy findings in Cetaceans from German waters of the North and Baltic Seas. Marine Pollution Bulletin 38, 285-295.

Siebert, U., Wunschmann, R., Weiss, R., Frank, H., Benke, H., Frese, K., 2001. Post-mortem findings in harbour porpoises (Phocoena phocoena) from the German North and Baltic Seas. Journal of Comparitive Pathology 124, 102-114.

Szefer, P., 2002. Metal pollutants and radionuclides in the Baltic Seaan overview. Oceanologia 44 (2), 129-178.

Tolley, K.A., Heldal, H.E., 2002. Inferring ecological separation from regional difference in radioactive caesium in harbour porpoises Phocoena phocoena. Marine Ecology Progress Series 228, 301309.

Van de Vijver, K.I., Hoff, P., Van Dongen, W., Esmans, E., Blust, R., De Coen, W., 2003a. Exposure patterns of perfluorooctane sulfonate in aquatic invertebrates from the Western Scheldt estuary and the Southern North Sea. Environmental Toxicology and Chemistry 22 (9), 2037-2041.

Van de Vijver, K.I., Hoff, P., Das, K., Van Dongen, W., Esmans, E., Jauniaux, T., Bouquegneau, J.M., Blust, R., De Coen, W., 2003b. Perfluorinated chemicals infiltrate ocean waters: link between exposure levels and stable isotope ratios in marine mammals. Environmental Science and Technology 37 (24), 55455550 .

\title{
Impact of the deposition of jarosite on deepwater meiobenthos in southeastern Australia
}

\author{
David Gwyther * \\ URS, L6, 1 Southbank Boulevard, Southbank, Vic. 3006, Australia
}

During the period 1973-1997, Pasminco Metals EZ (PMEZ; now Pasminco Hobart Smelter) disposed of its jarosite residue from zinc smelting at an offshore ocean disposal site approximately $100 \mathrm{~km}$ southeast of Hobart, Tasmania in depths of around $2000 \mathrm{~m}$ (Fig. 1). The jarosite was released as slurry from a barge (MV Anson) within a target $2 \mathrm{~km}$ radius disposal area. The jarosite was a fine-grained, high-moisture content mixture of ammonium jarosite (principally iron, ammonium and sulphate), gypsum and calcine residue, containing maximum allowable concentrations of zinc $(6.5 \%)$, lead $(2.4 \%)$, arsenic $(0.95 \%)$, copper $(0.24 \%)$ and mercury $(0.00015 \%)$ and in total, about $4 \mathrm{Mt}$ of waste was disposed (CSIRO, 1994). The modal grain size of jarosite was about $10 \mu \mathrm{m}$. Approximately $60 \%$ of the material was either dissolved or remained in suspension for sufficient time to be carried out of the disposal site, the remainder being deposited as a thin layer $0.1-0.6 \mathrm{~mm}$ thick (CSIRO, 1994). However, through processes of

\footnotetext{
${ }^{*}$ Present Address: Enesar Pty Ltd, 124 Camberwell Road, Hawthorn East, Vic. 3123, Australia. Tel.: +61-3-9882-3555; fax: +61-39882-3533.

E-mail address: david.gwyther@enesar.com.au (D. Gwyther).
}

agglomeration or adhesion to other organic matter, the proportion of the jarosite that could reach the seabed could have exceeded $40 \%$ of the disposed material. This study of benthic impacts formed part of the conditions of a 2 year renewal of PMEZ's jarosite disposal permit from 1995 until ocean disposal ceased in 1997, which was required to meet international obligations under the 1996 Protocol to the London Convention.

The study was part of a wider investigation of the bathymetry and continental slope processes of the disposal area, undertaken to obtain more accurate data on accumulation depths of jarosite and any subsequent, down-slope dispersal (Harris et al., 1999). This study examined the surface (top $2 \mathrm{~cm}$ ) for meiofauna, these being more numerous than macrofauna at depths from which the cores were retrieved (Higgins and Thiel, 1988). Some of the advantages of using the meiofauna in impact studies are also discussed by Coull and Chandler (1992) and Kennedy and Jacoby (1999).

Seabed core samples were obtained from the jarosite settlement and control areas to investigate the impacts of jarosite on benthic fauna of the jarosite disposal area. Without any prior information on the likely distribution, abundance and variability of meiofauna in 